Tatiana Liptáková

Ayman Alaskari

Libor Trško

Sylvia Dundeková

https://doi.org/10.21278/TOF.41307

ISSN 1333-1124

eISSN 1849-1391

\title{
CORROSION RESISTANCE OF AISI 316Ti STAINLESS STEEL SUBJECTED TO SHOT PEENING WITH AND WITHOUT PICKLING IN VARIOUS CHLORIDE ENVIRONMENTS
}

\begin{abstract}
Summary
Surface conditions of materials affect the chemical, physical and mechanical properties of stainless steels. The main interest of this paper is to focus on corrosion properties of the AISI 316Ti stainless steel treated by shot peening and shot peening and pickling. In the last years shot peening has been widely used as a method improving fatigue properties of components under cyclical load. Because surface finishing has strong effect on corrosion susceptibility of stainless steels, e. g. pitting and created pits can initialize cracks, it is important to analyse corrosion behaviour of the material in question. In this study, the tested surfaces were characterized by SEM, EDX analyses, measurement of surface free energy and roughness. Corrosion properties were investigated in various environments by exposure, potentiodynamic cyclic and EIS tests.
\end{abstract}

Key words: $\quad$ shot peening, stainless steel, corrosion, pitting

\section{Introduction}

Stainless steels are very important construction materials because of their mechanical properties and corrosion resistance to various environments. Therefore, they are used in areas where high safety, reliability and lifetime are demanded (energy industry, medical instruments and implants, pharmaceutical and food processing industry etc.) [1,2]. In spite of the fact that stainless steels exhibit very good corrosion resistance in conventional conditions they are susceptible to local corrosion attacks (pitting) in specific environments, especially if chlorides are present. Their corrosion behaviour is affected by many factors, such as chemical composition, microstructure and surface condition of the material [3 - 5]. According to the authors [6] small dimensions of corrosion pits, short timescale of corrosion pits in metastable state, dynamic interplay between heterogeneous surface and changing potential and solution concentration gradients complicate the development of a complete understanding of the phenomena of local corrosion. Our study focuses on an investigation into the corrosion behaviour of the AISI 316Ti stainless steel with the surface treated by shot peening. The tests were carried out by applying several experimental methods in solutions with a constant $\mathrm{Cl}^{-}$ concentration with and without oxidizing agents. 
The surface of stainless steels prepared by a mechanical or chemical method influences the corrosion properties by affecting passive layers properties, changing the surface reactivity and altering the near surface residual stress. Surface roughness resulting from the applied finishing processes can also be an important factor in the subsequent corrosion behaviour. As a result, surface treatment operations can alter the resistance of steel to the initiation and propagation of pitting. The mentioned problems have been studied extensively by many authors over the last 50 years on the basis of different laboratory approaches [7 - 10]. In the last years, surface treatment of stainless steels (e.g. shot peening) is investigated with the aim of improving their fatigue properties [11 - 13]. Shot peening changes the surface properties, therefore it is necessary to study its influence on susceptibility to a local form of corrosion where pits can operate as crack initializers [14]. Wang and $\mathrm{Yu}$ [15] found that higher corrosion resistance to pitting in chloride solutions can be achieved through surface nanocrystallization induced by high energy shot peening of the 1Cr18Ni9Ti stainless steel. Onizawa et al. [16] observed an increase in corrosion and fatigue resistance of the high nitrogen austenitic stainless steel (RS561) after shot peening was carried out. According to authors [17] a fine particle peening treatment on the 316L stainless steel prior to gas nitriding resulted in higher fatigue life In this study, changes in the surface parameters of the AISI 316Ti stainless steel finished by shot peening and shot peening + pickling are evaluated as well as their effect on the corrosion properties in various solutions (constant content of chlorides but different concentration of oxidizing ions). Various experimental methods were used to compare the corrosion behaviour of the tested surfaces during different control phases of the corrosion process.

\section{Experiments and results}

To investigate the effect of shot peening and shot peening and pickling on corrosion properties of the AISI 316Ti stainless steel, corrosion tests with different mechanisms were used. Thus it was possible to compare corrosion resistance of specimens with different surface states in various environments.

\subsection{Characterization of experimental material}

The specimens of the experimental material were produced of the AISI 316Ti austenitic stainless steel with the chemical composition shown in Table 1. The microstructure of the original material investigated by using the optical metallographic microscope can be seen in Figure 1. The microstructure of the AISI 316Ti stainless steel is composed of polyedric austenitic grains with deformation twins. In Figure $1 \delta$-ferrite and $\mathrm{Cr}$ and Mo carbides were identified.
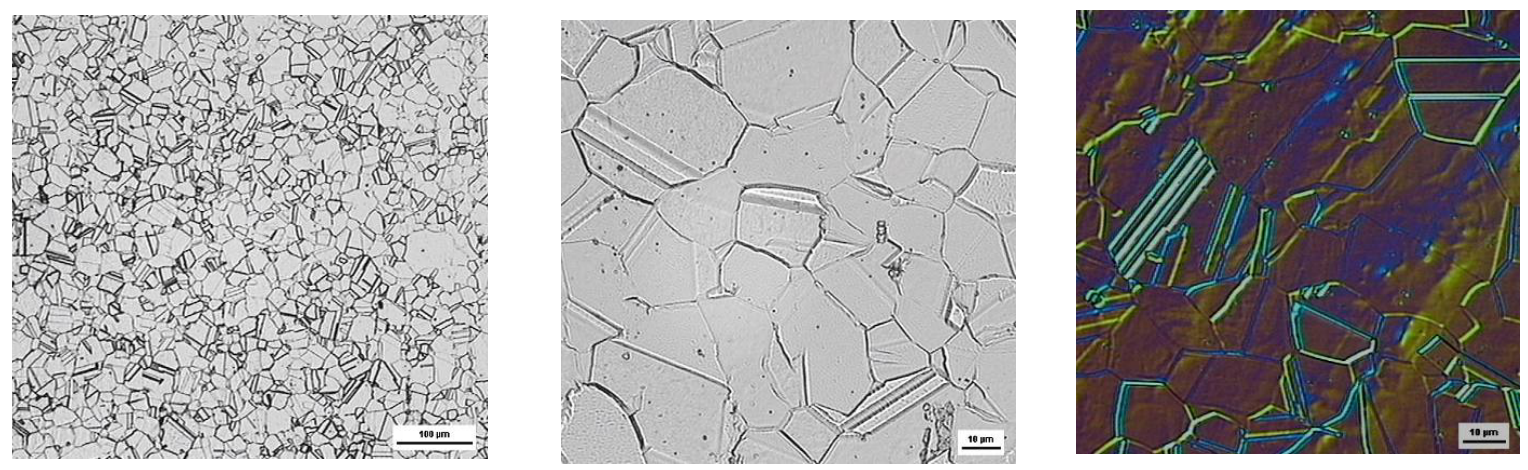

Fig. 1 Microstructure of cross section of AISI 316Ti steel

Table 1 Chemical composition of the AISI 316Ti steel

\begin{tabular}{|c|c|c|c|c|c|c|c|c|c|c|c|}
\hline $\begin{array}{c}\text { Element } \\
\text { content } \\
\text { [wt.\%] }\end{array}$ & $\mathbf{C r}$ & $\mathbf{N i}$ & $\mathbf{M o}$ & $\mathbf{M n}$ & $\mathbf{N}$ & $\mathbf{T i}$ & $\mathbf{C}$ & $\mathbf{S i}$ & $\mathbf{P}$ & $\mathbf{S}$ & $\mathbf{F e}$ \\
\cline { 2 - 11 } & 10.6 & 2.12 & 1.69 & 0.012 & 0.41 & 0.04 & 0.43 & 0.026 & 0.002 & balance \\
\hline
\end{tabular}




\subsubsection{Surface treatment of experimental specimens}

The surfaces of specimens were prepared by shot peening with steel balls (diameter from 0.20 to $0.7 \mathrm{~mm}$ ) of the steel with nearly the same chemical composition as the experimental material, the pressure was $0.4 \mathrm{MPa}$, the distance of the jet $220 \mathrm{~mm}$. One half of the shot peened specimens was finished by pickling (in the solution of 1 portion of the hydrofluoric (HF) acid 40\%, 20 portions of the $63 \% \mathrm{HNO}_{3}$ solution and 79 portions of distilled water), the exposure time was 30 minutes at a temperature of $22 \pm 1{ }^{\circ} \mathrm{C}$. The character of the surfaces treated by shot peening $(\mathrm{S})$ and shot peening and pickling $(\mathrm{S}+\mathrm{P})$ was studied by a scanning electron microscope (SEM) (Fig. 2). At the point of the steel ball impact the surfaces were plain and their surrounding had a very non-homogenous broken topography (Fig. 2a). According to the authors [11] the parameters of the atomic lattice are changed by this surface treatment and an increase in the residual stress in the surface is caused. It is also expected that the surface oxide layers are pressed under the surface by shot peening, some crevices are created and this can cause a danger of a local corrosion attack. Pickling commonly removes impurities from the surface and increases homogeneity and integrity of passive oxide layers. The effect of pickling on the surface character is evident and it can be seen in Fig $2 b$. In this figure, the crevices are deeper and the surface topography is more difficult. Changes in the chemical composition ( $\mathrm{S}$ and $\mathrm{S}+\mathrm{P}$ ) made by the EDX analysis are presented in Table 2. The main change has been recorded in the content of oxygen (homogeneity of the passive layer).
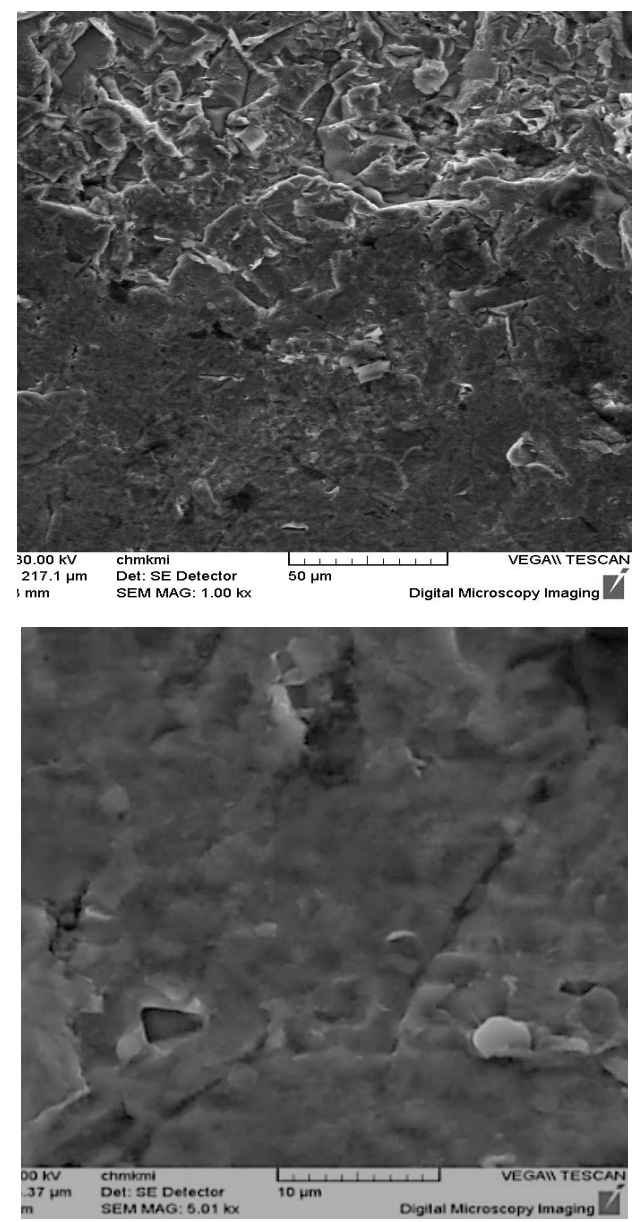

Fig. 2a SEM images of shot peened surface
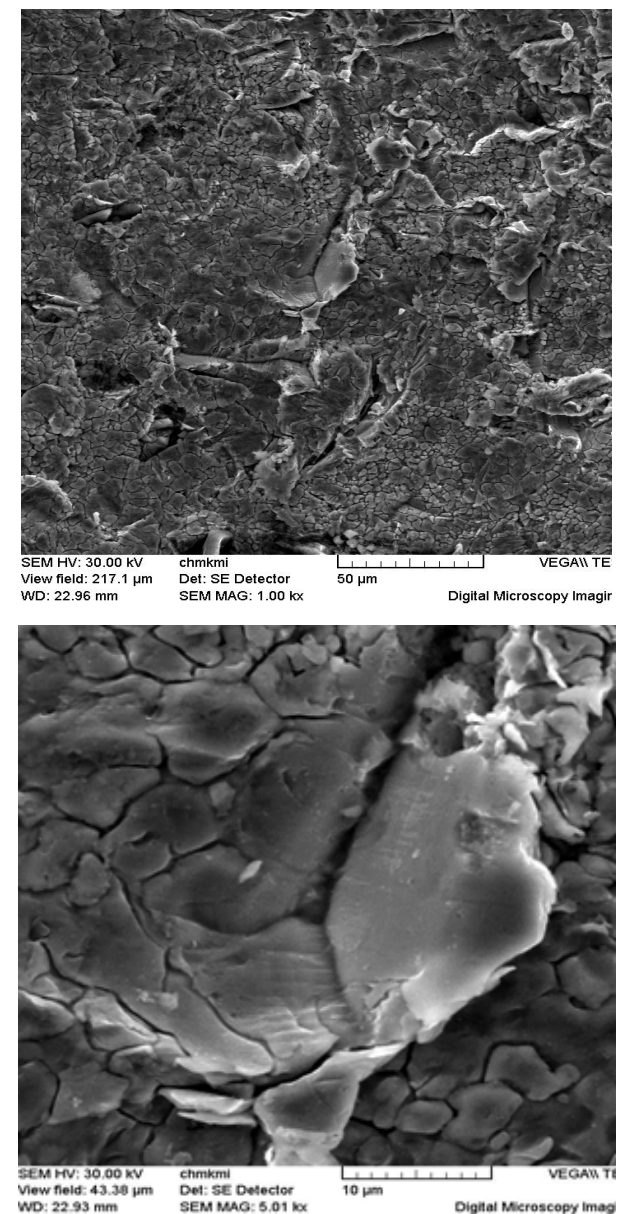

Fig. 3b SEM images of shot peened + pickled surface 
T. Liptáková, A. Alaskari,

L. Trško, S. Dundeková
Corrosion Resistance of AISI 316Ti Stainless Steel Subjected to Shot Peening with and without Pickling in Various Chloride Environments

Table 2 Chemical composition of the surfaces $\mathrm{S}$ and $\mathrm{S}+\mathrm{P}$

\begin{tabular}{|c|c|c|}
\hline \multicolumn{3}{|c|}{ S } \\
\hline Element & $\begin{array}{c}\text { C norm. } \\
\text { [wt. \%] }\end{array}$ & $\begin{array}{c}\text { C atom. } \\
\text { [at.\%] }\end{array}$ \\
\hline $\mathrm{O}$ & 6.90 & 20.12 \\
\hline $\mathrm{Al}$ & 1.05 & 1.82 \\
\hline $\mathrm{Si}$ & 1.59 & 2.65 \\
\hline $\mathrm{Ti}$ & 0.40 & 0.39 \\
\hline $\mathrm{Cr}$ & 13,40 & 12.02 \\
\hline $\mathrm{Mo}$ & 1.85 & 0.90 \\
\hline $\mathrm{Fe}$ & 65.43 & 54.65 \\
\hline $\mathrm{Ni}$ & 9.37 & 7.45 \\
\hline \multicolumn{2}{|c}{} \\
\hline
\end{tabular}

\begin{tabular}{|c|c|c|}
\hline \multicolumn{3}{|c|}{$\mathbf{S + P}$} \\
\hline Element & $\begin{array}{c}\text { C norm. } \\
{[\mathbf{w t . \%} \text { ] }}\end{array}$ & $\begin{array}{c}\text { C atom. } \\
\text { [at.\%] }\end{array}$ \\
\hline $\mathrm{O}$ & 2.45 & 7.89 \\
\hline $\mathrm{Al}$ & 0.25 & 0.48 \\
\hline $\mathrm{Si}$ & 0.63 & 1.15 \\
\hline $\mathrm{Ti}$ & 0.42 & 0.45 \\
\hline $\mathrm{Cr}$ & 15.65 & 15.52 \\
\hline $\mathrm{Mo}$ & 1.57 & 1.48 \\
\hline $\mathrm{Fe}$ & 68.19 & 62.96 \\
\hline $\mathrm{Ni}$ & 10.11 & 8.88 \\
\hline
\end{tabular}

The geometry of the examined surfaces was evaluated by measuring the mean values of roughness $\mathrm{Ra}$ (arithmetical mean deviation of the profile) and $\mathrm{Rz}$ (maximum height of the profile) and by comparing both ground and pickled surfaces, see Table 3 . It can be seen that $\mathrm{Ra}$ of the surfaces finished by shot peening and pickling have higher values. The profiles of the tested surfaces are shown in Fig 3. The segmentation of the surface means also that the real surface area is larger. This fact can also affect the kinetics of the corrosion process.

Table 3 Roughness of the tested surfaces in the longitudinal and transverse direction

\begin{tabular}{|c|c|c|c|c|}
\hline$[\boldsymbol{\mu m}]$ & $\mathbf{G}$ & $\mathbf{G}+\mathbf{P}$ & $\mathbf{S}$ & $\mathbf{S}+\mathbf{P}$ \\
\hline Long. $\mathbf{R a}$ & 0.151 & 0.391 & 4.072 & 8.757 \\
\hline Trans.Ra & 0.185 & 0.299 & 3.931 & 9.084 \\
\hline Long. $\mathbf{R z}$ & 1.69 & 3.46 & 35.1 & 52.8 \\
\hline Trans.Rz & 1.89 & 2.44 & 38.3 & 55.2 \\
\hline
\end{tabular}
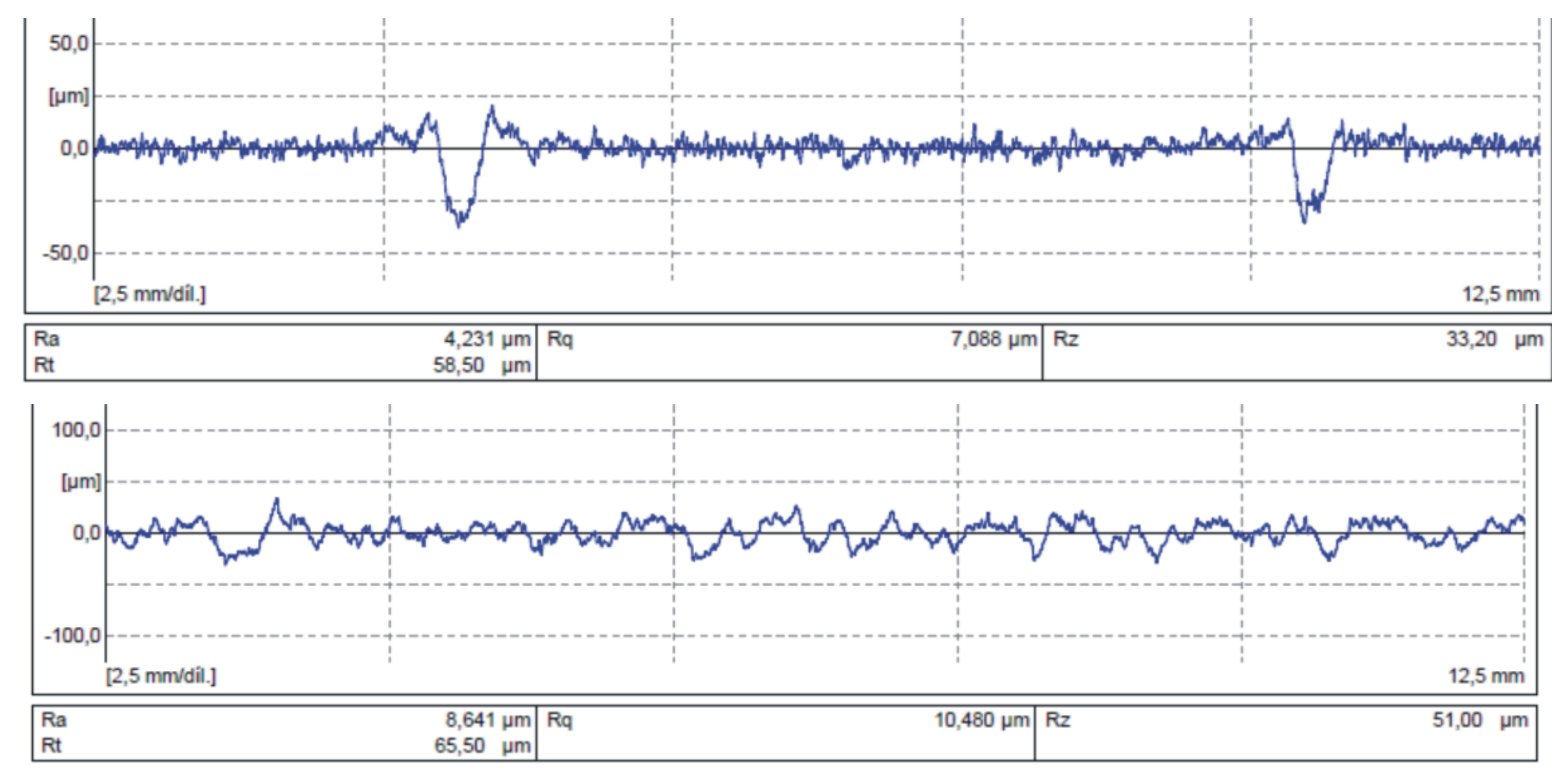

Fig. 3 Comparison of representative surface roughness determined on specimens: $\mathrm{S}$ and $\mathrm{S}+\mathrm{P}$ surfaces in longitudinal direction

For the specimens $\mathrm{S}$ and $\mathrm{S}+\mathrm{P}$ the surface free energy (SFE) was measured by applying the Owen-Wendt method because of its influence on the adsorption of reactants contained in the environment on the metal surface [18]. The mean value of the SEF of the shot peened specimens was $42.43 \mathrm{~mJ} / \mathrm{m}^{2}$ and after pickling it grew to $95.45 \mathrm{~mJ} / \mathrm{m}^{2}$. Comparing the SFE with a standard finished surface of the same material (grinding), the measured SFE of the ground surface was $43.92 \mathrm{~mJ} / \mathrm{m}^{2}$ and after pickling it also rose to the value of $59.36 \mathrm{~mJ} / \mathrm{m}^{2}$. 


\subsection{Corrosion testing}

The corrosion properties of the variously treated AISI 316Ti stainless steel were studied by using three types of corrosion tests (exposure, potentiodynamic cyclic test, EIS). All the used tests differ with respect to the evaluation of the corrosion process in the same conditions and because of that it is possible to identify which parameters are effective for various surface states in various environments $[19,20]$.

\subsubsection{Exposure test}

The tests were performed in a $5 \% \mathrm{NaCl}$ solution with redox potential of $291 \mathrm{mV}$ (solution 1)), in a $4.6 \% \mathrm{FeCl}_{3}$ solution with redox potential of $674 \mathrm{mV}$ (solution 2) and in a solution which is a mixture of $50 \%$ of $4.6 \% \mathrm{FeCl}_{3}$ and $50 \%$ of $5 \% \mathrm{NaCl}$ solution with redox potential of $671 \mathrm{mV}$ (solution 3). The redox potential was read relative to a redox electrode SHE with $\mathrm{E}=+207 \mathrm{mV}$ at a temperature of $23^{\circ} \mathrm{C}$. The $\mathrm{pH}$ of solution 1 was 6.8 , of solution 2 it was 1.12 and of solution 3 it was 1.51 due to a strong acidic reaction of $\mathrm{FeCl}_{3}$. The reason why these solutions were chosen is their different oxidizing ability and $\mathrm{pH}$ at the same concentration of $\mathrm{Cl}^{-}$ions. The experimental temperature during the test was $21 \pm 2{ }^{\circ} \mathrm{C}$. The exposure time in the solutions was 72 hours. After exposure the specimens were cleaned in distilled water and dried so no corrosion products were left on the surfaces. The weight losses were determined with an accuracy of $10^{-5} \mathrm{~g}$. The calculated main corrosion rates in solution 1 , 2 and 3 are given in Table 4. The corrosion rates of specimen $\mathrm{S}$ in the $\mathrm{NaCl}$ solution are very low and after having undergone pickling $(\mathrm{S}+\mathrm{P})$ they were reduced almost five times. The corrosion rates in solution 2 are very similar for both tested surfaces, and pickling decreased the corrosion resistance of shot peened specimens negligibly. The differences in solution 3 after pickling have been determined to be higher. The size and density of the corrosion pits were determined according to the standard STN ISO 11463. On specimens S and S+P after exposure in solution 3 no differences in the pit size (2B) and density (2A) were established. In solution 2 on specimens $\mathrm{S}$ the pit size was $2 \mathrm{~B}$ but of a higher density $3 \mathrm{~A}$, and on the pickled samples no change in size was identified but only in the density of corrosion pits. No corrosion pits were found in solution 1. In comparison with the corrosion rates of the AISI 316Ti steel treated by grinding and grinding + pickling in solution 1 negligible differences were found, but in solutions 2 and 3 the corrosion rates of ground and pickled specimens were about two times higher than that of the ground specimens. In both types of mechanical treatment pickling increased the corrosion rates in the environments containing oxidizing ions $[21,22]$. The effect of surface roughness and the value of the SFE after pickling become evident in the oxidizing solutions.

Table 4 Corrosion rates of the tested specimens

\begin{tabular}{|c|c|c|}
\hline Specimen/corr. rate $\left({\left.\mathrm{g} . \mathrm{cm}^{-2} \cdot \mathrm{day}^{-1}\right)}^{-1}\right.$ & S & $\mathbf{S}+\mathbf{P}$ \\
\hline Solution 1 & $0.232 \times 10^{-4}$ & $0.052 \times 10^{-4}$ \\
\hline Solution 2 & 0.0180 & 0.0184 \\
\hline Solution 3 & 0.0116 & 0.0145 \\
\hline
\end{tabular}

\subsubsection{Potentiodynamic cyclic test}

The potentiodynamic cyclic tests were carried out on a VoltaLab (Radiometer Analytical) device according to ASTM G61-86 (reapproved 2009) "Standard Test Method for Conducting Cyclic Potentiodynamic Polarization Measurements for Localized Corrosion Susceptibility of $\mathrm{Fe}, \mathrm{Ni}$, Co-based alloys". Using this method the pitting potential $\mathrm{E}_{\mathrm{dp}}$ (potential of depassivation) and the repassivation potential $\mathrm{E}_{\mathrm{rp}}$ of the tested specimens were 
measured. The measurements were made in solution 1 . The conditions of the potentiodynamic cyclic test were: the initial potential was $-200 \mathrm{mV}$, the potential maximum was $900 \mathrm{mV}$, and the rate of potential change was $10 \mathrm{mV} / \mathrm{min}$ measured relative to a saturated calomel electrode (SCE). The time for free potential stabilization of specimens was 5 minutes. The results are presented in Table 5 and the potentiodynamic curves can be seen in Fig. 4.

Table 5 Results of potentiodynamic test

\begin{tabular}{|c|c|c|c|c|}
\hline specimen & $\mathbf{E}_{\mathbf{d p}}(\mathbf{m V})$ & $\mathbf{E}_{\mathbf{r p}}(\mathbf{m V})$ & $\mathbf{E}_{\mathbf{c o r r}}(\mathbf{m V})$ & $\mathbf{i}_{\mathbf{c o r r}}\left(\mathbf{m A} / \mathbf{c m}^{2}\right)$ \\
\hline $\mathbf{S}$ & 182.2 & -241.3 & -272.1 & 0.003 \\
\hline $\mathbf{S}+\mathbf{P}$ & 418.8 & -158.7 & -193 & 0.007 \\
\hline
\end{tabular}

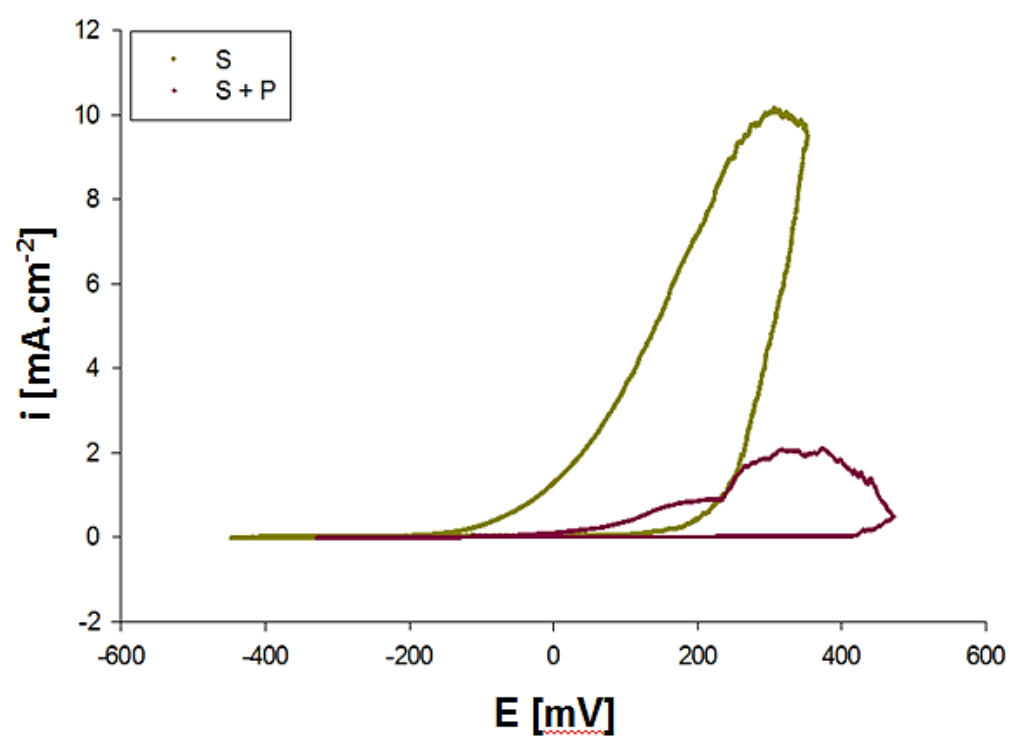

Fig. 4 Potentiodynamic curves of the tested AISI 316Ti steel with various finishes

Potential $E_{d p}$ of the shot peened surfaces is evidently shifted after pickling to more positive values, which means that the shot peened surfaces exhibit higher electrochemical stability. This proves that pickling affects the protective effectivity of the passive layer. In comparison with the ground surface according to [23, 24], the measured electrochemical characteristics were worse. According to the potentiodynamic cyclic test results a positive effect of pickling is visible on the tested surfaces. In this type of test the character of a passive layer (purity, homogeneity) is very important.

\subsubsection{Electrochemical impedance spectroscopy}

The electrochemical impedance spectroscopy (EIS) experiments were carried out on a VoltaLab (Radiometer Analytical) device. The conditions of experiments were: the time for potential stabilization between specimen and electrolyte (solutions 1, 2, 3) was 10 minutes, the frequency was in a range from $100 \mathrm{kHz}$ to $1 \mathrm{mHz}$ with 10 -times frequency change per decade, the amplitude of the alternating current $\mathrm{AC}$ voltage was $20 \mathrm{mV}$. The direct current DC) voltage, which polarizes the specimen during the test, was set to the measured value of free potential after 10 minutes of stabilization. The EIS tests were performed at a laboratory temperature $\left(21 \pm 1{ }^{\circ} \mathrm{C}\right.$ by using a conventional three-electrode cell system with a reference $\mathrm{SCE}\left(\mathrm{Hg} / \mathrm{Hg}_{2} \mathrm{Cl}_{2} ; \mathrm{KCl}_{\text {saturated }}\right)$ and a platinum auxiliary electrode $(\mathrm{Pt})$. The impedance $\mathrm{Z}$ of the equivalent circuit was calculated for a typical simplified Randles cell $[25,26]$. The values of the specimen polarization resistances $R_{p}$ were determined from the Nyquist diagrams 
(Figure 5-7) and the values of the chosen characteristic in solutions 1, 2 and 3 are given in Table 6. The diagrams show differences caused by different redox potential of the testing solutions with the same $\mathrm{Cl}^{-}$concentration.

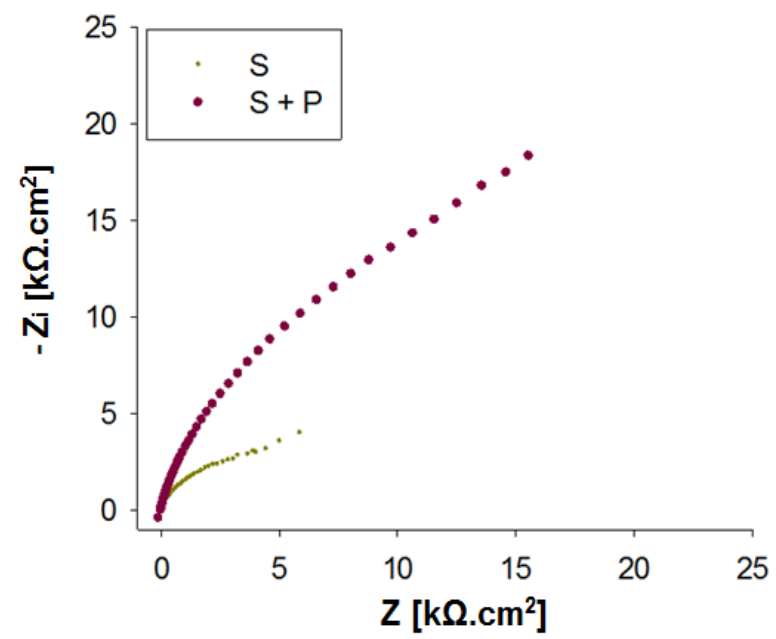

Fig. 5 Results of EIS test in solution 1

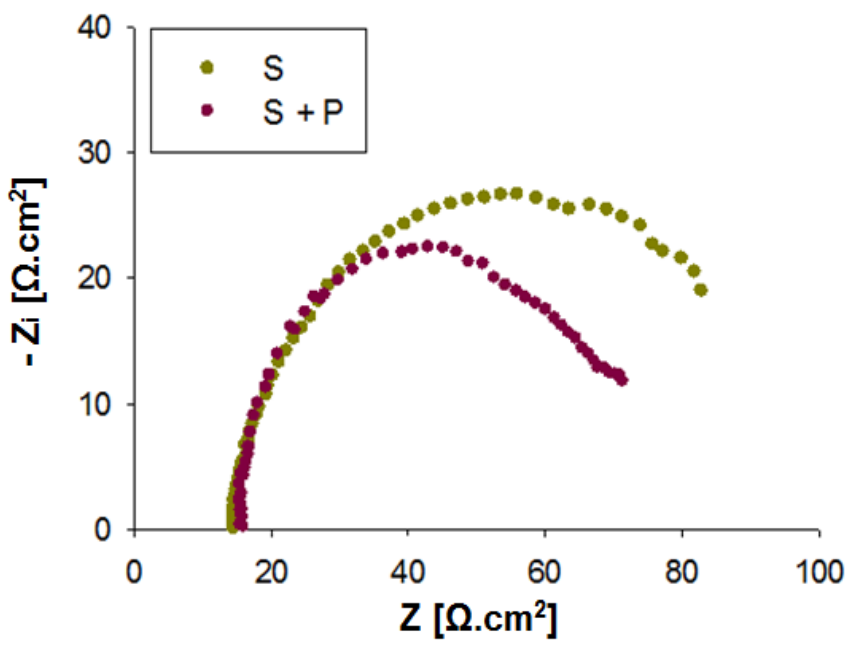

Fig. 6 Results of EIS test in solution 2

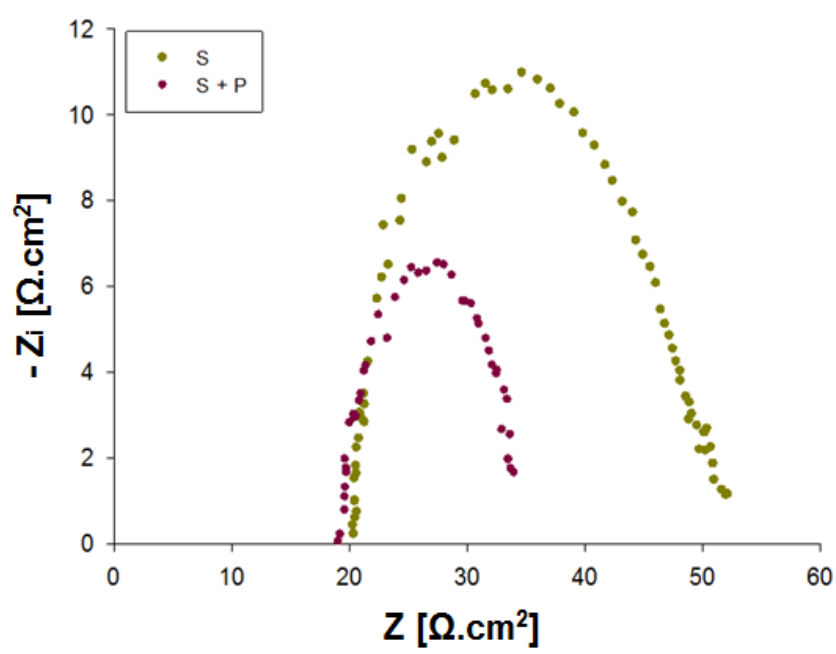

Fig. 7 Results of EIS test in solution 3 
T. Liptáková, A. Alaskari,

L. Trško, S. Dundeková
Corrosion Resistance of AISI 316Ti Stainless Steel Subjected to Shot Peening with and without Pickling in Various Chloride Environments

Table 6 Polarization resistance in solutions 1, 3 and 2

\begin{tabular}{|c|c|c|c|}
\hline specimen $\backslash$ solution & $\begin{array}{c}\mathbf{N a C l} / \mathbf{1} \\
\mathbf{R p}\left[\mathbf{\Omega . c m}{ }^{-2}\right]\end{array}$ & $\begin{array}{c}\mathbf{F e C l} \mathbf{3} / \mathbf{2} \\
\mathbf{R p}\left[\mathbf{\Omega . c m}{ }^{-2}\right]\end{array}$ & $\begin{array}{c}\mathbf{N a C l}+\mathbf{F e C l}_{\mathbf{3}} / \mathbf{3} \\
\mathbf{R p}\left[\mathbf{\Omega . c m}^{-2}\right]\end{array}$ \\
\hline $\mathbf{S}$ & $11.31 \times 10^{3}$ & 31.38 & 66.79 \\
\hline $\mathbf{S}+\mathbf{P}$ & $112.6 \times 10^{3}$ & 15.06 & 55.13 \\
\hline
\end{tabular}

The results of the EIS tests in the testing solutions suggest a positive influence of pickling in chloride solution 1 without oxidizing ions $\mathrm{Fe}^{+3}$, but in solutions 2 and 3 corrosion resistance falls as the amount of oxidizing ions increases. The results correspond with the results of the exposure tests.

\section{Conclusions}

- Shot peening in an aggressive chloride solution reduces corrosion resistance of the AISI 316Ti stainless steel to pitting in comparison with conventional ways of finishing (e.g. grinding). The difference in corrosion behaviour can be caused by changes in the surface characteristics e.g. bigger real surface area and different surface energy.

- The effect of the surface treatments of shot peening and shot peening and pickling of specimens on the corrosion behaviour in an only chloride solution was not dependent on the test method. In the solutions with the same chloride concentration but different oxidizing power and lower value of $\mathrm{pH}$ the pickling of the shot peened surface had a negative influence on corrosion resistance according to the results of the exposure and EIS tests. The different concentration of oxidizing ions (solution 2 and 3) did not affect substantially the corrosion behaviour of the specimens with different surface treatment.

- The application of tests with different control phases of the corrosion process (potentiodynamic, EIS and immersion tests) has enabled a more precise determination of corrosion behaviour in various environments and a comparison of the surface parameters effect.

- The AISI 316Ti stainless steel with the surface treated by shot peening is not especially susceptible to pitting corrosion in an environment containing chlorides; however, the present oxidizing reactants evidently increase susceptibility to pitting corrosion.

\section{ACKNOWLEDGEMENT}

The research is supported by the European regional development fund and the Slovak state budget within the project "Research center of University of Žilina - Second Phase", ITMS 26220220183 and projects APVV No. APVV-14-0284 and APVV-15-0120.

\section{REFERENCES}

[1] Black, J. Biological performance of materials: Fundamentals of Biocompatibility. $4^{\text {th }}$ ed. Boca Raton, CRC Press, 2006. 497 s. ISBN 0-8493-3959-6.

[2] Č́íhal, V. Stainless steels and alloys. (in Czech) Praha : Academia, 1999.

[3] Liptáková, T. Pitting corrosion of stainless steels (in Slovak) Žilina : University of Žilina EDIS ŽU, 2009. s. 63. 978-80-554-0083-9. 
[4] Szklarska; Salowska, Z. Pitting and crevice corrosion. Huston, Texas: NACE International 2005. $610 \mathrm{~s}$. ISBN: 978-1-57590-185-5

[5] Rodabaugh, R.D. Surface cleaning. ASM Handbook Vol.5 Surface enginering. $3^{\text {th }}$ edition, ASM International. USA. 1999. ISBN 0-87170-384-X.

[6] Frankel G.S.; Sridhar N. Understanding localized corrosion, Materials today, Vol. 11, No. 10, 2008, pp. 38. https://doi.org/10.1016/S1369-7021(08)70206-2

[7] Moyed, M.H.; Layckock, N.J.; Newman, R.C. Dependence of the critical pitting temperature on surface roughness, Corrosion Science, 45, 2003, pp. 1203. https://doi.org/10.1016/S0010-938X(02)00215-9

[8] Bausamy, T.; Saniara Narayanan, T.S.N.; Ravichandran, K.; Park, I.S.; Lee, M.H. Influence of surface mechanical attrition (SMAT) on corrosion behavior of AISI 304 stainless steel. Corrosion Science, 74, 2013, pp. 332. https://doi.org/10.1016/j.corsci.2013.04.056

[9] Ladwein, T.L.; Sorg, M.; Schilling, S. Influencing the functional properties of stainless steels by different surface treatments. Corrosion Conference and Expo 2011. Proceedings; 2011 March 13 - 17, Texas USA

[10] Sasaki, K.; Burstein, G.T. The generation of surface roughness during slurry erosion-corrosion and its effect on the pitting potential. Corros. Sci. 1996; 38:2111-2120. https://doi.org/10.1016/S0010-938X(96)00066-2

[11] Guagliano, M.; Trško L.; Bokuvka O.; Nový F. Influence of Shot Peening on AISI 316Ti Fatigue Properties. Material Engineering, Vol. 19, No.3, 2012, pp.117.

[12] Trško L.; Guagliano M.; Bokuvka O.; Nový F. Fatigue life of AW 7075 Aluminium Alloy after Severe Shot Peening Treatment with Different Intensities. Procedia Engineering, Volume 74, 2014, pp. 246. https://doi.org/10.1016/j.proeng.2014.06.257

[13] Balker, S. Shot peening: A Dynamic, Application and its Future, second edition, MFN Zürich, 2006.

[14] Speidel, M.O. Effect of shot peening on stress corrosion cracking and corrosion fatigue, Institute of Metallurgy, Swiss Federal Institute of Technology, ETH-Zentrum CH-8092 Zürich, Switzerland, pp. 625.

[15] Wang, T.; Yu, J.; Dong, B. Surface nanocrystallization induced by shot peening and its effect on corrosion resistance of 1Cr18Ni9Ti stainless steel. Surf. Coat. Technol. 200. 2006, pp. 4777-81. https://doi.org/10.1016/j.surfcoat.2005.04.046

[16] Onizawa, A.; Islam, M.A.; Ojima, M.; Tomota, Y. Fatigue properties of smooth and as-shot peened $\mathrm{n}$ bearing austenitic stainless steel under tension-tension condition. ARPN J. Eng. Appl. Sci. 1. 2006, pp. 1221.

[17] Kikuchi, S.; Nakahara, Y.; Komotori, J. Fatigue properties of gas nitrided austenitic stainless steel pretreated with fine particle peening. Int. J. Fatigue 32. 2010, pp. 403-410. https://doi.org/10.1016/j.ijfatigue.2009.07.019

[18] Rudawska, A.; Jacniacka, E. Analysis for determining surface free energy uncertainty by the Owen Wendt method. International journal of adhesion and adhesives. Elsevier, 29 (4) 2009, pp. 451.

[19] Baboian, R. 1995. Corrosion tests and standards: application and interpretation. Philadelphia. USA. ISBN 0-8031-2058-3. 1995.

[20] Markus, P. et al. (sec. ed.). Marcel Decker Inc. New York. 2002. (first ed.) in Corrosion Science. ISSN 0010-938X). 2008.

[21] Liptáková, T.; Zatkalíková, V. The Variability of Chemical Composition of the AISI 213 Ti and Pitting Transaction of Famena, 33, 1, 2009, pp. 31.

[22] Fajnor, P. Influence of surface finishing on corrosion resistance of stainless steel AISI 316Ti from the point of pitting corrosion (in Slovak) [dissertation]. Žilina (SK): University of Žilina; 2012.

[23] Liptáková T.; Bolzoni F.; Trško L. Specification of surface parameters effects on corrosion behavior of the AISI 316Ti in dependence on experimental methods. Journal of Adhesion Science and Technology, 30(21), 2016, p. 2329-2344. https://doi.org/10.1080/01694243.2016.1182824

[24] Alaskari, A.; Liptáková, T.; Fajnor, P.; Halamová, M. Mechanical surface treatments effects on corrosion of AISI316 Ti stainless steel in chloride environments. Journal Of Engineering Research Vol. 2 No. 3 , 2014, p. 195-210. https://doi.org/10.7603/s40632-014-0020-1

[25] Mansfeld, F.; Lorenz, W.J. Electrochemical Impedance spectroscopy (EIS): Application in corrosion science and technology. New York: Techniques for characterization of electrodes and electrochemical processes. John Wiley and sons. New York. 1991.

[26] Dunn, D.S.; Sridhar, N. In Situ study of salt film stability in simulated pits of nickel by Raman and electrochemical impedance spectroscopies. Journal of Electrochemical Society. Vol. 144. Issue 12. Pennington. USA. ISSN 0013-4651. 1997. pp. 4243-4253. 
T. Liptáková, A. Alaskari,

L. Trško, S. Dundeková
Corrosion Resistance of AISI 316Ti Stainless Steel Subjected to Shot Peening with and without Pickling in Various Chloride Environments

\section{USED STANDARDS}

[1] ASTM G48-2003 (reapproved 2009) "Standard Test Methods for Pitting and Crevice Corrosion Resistance of Stainless Steels and Related Alloys by Use of Ferric Chloride Solution" 2009.

[2] ASTM G61-86 (reapproved 2009) "Standard Test Method for Conducting Cyclic Potentiodynamic Polarization Measurements for Localized Corrosion Susceptibility of Fe, Ni, Co-based alloy" 2009.

[3] STN ISO 11463:1995 "Corrosion of metals and alloys - Evaluation of pitting corrosion" 1995.

Submitted: $\quad 19.02 .2016$

Accepted: $\quad 02.02 .2017$
Tatiana Liptáková

University of Žilina, Faculty of

Mechanical Engineering, Department of

Material Engineering, Univerzitná 8215/1, 01026 Žilina, Slovakia

Ayman Alaskari

Department of Mechanical Manufacturing

Engineering Technology, College of

Technological Studies, PAAET, Kuwait

Libor Trško

Sylvia Dundeková

Research Centre of the University of Žilina, Univerzitná 8215/1, 01026 Žilina, Slovakia 